Sintesis zeolit dari abu dasar batubara dan aplikasinya... (Ma'rifat, dkk.)

\title{
SINTESIS ZEOLIT DARI ABU DASAR BATUBARADAN APLIKASINYA SEBAGAI ADSORBEN LOGAM MERKURI (II)
}

\section{SYHTHESIS OF ZEOLITE FROM CHARCOAL BOTTOM ASH AND IT'S APPLICATION AS ADSORBENTFOR MERCURY (II)}

\author{
Ma'rifat, Didik Krisdiyanto ", Khamidinal dan Irwan Nugraha \\ Jurusan Kimia, Fakultas Sains dan Teknologi , UIN Sunan Kalijaga Yogyakarta \\ *email: didik_kris@yahoo.com
}

\begin{abstract}
ABSTRAK
Telah dilakukan sintesis zeolit dari abu dasar batubara dan aplikasinya sebagai adsorbenuntuk logam merkuri (II). Zeolit disintesis dengan metode alkali hidrotermal dan dikarakterisasi menggunakan Spektrofotometer FTIR dan Difraktometer Sinar-X (XRD). Kajian adsorpsi zeolit terhadap logam merkuri (II) dilakukan dengan variasi $\mathrm{pH}$,waktu kontak dan konsentrasi merkuri. Karakterisasi FTIR menunjukkan bahwa zeolit telah terbentuk dengan serapan pspesifik pada bilangan gelombang 457,31 $\mathrm{cm}^{-1}$.Hasil karakterisasi XRD menunjukkan bahwa zeolit hasil sintesis mempunyai struktur material zeolit faujasit yang ditunjukkan dengan difraksi utama pada $6,29^{\circ} ; 26,89^{\circ}$; dan $31,19^{\circ}$. Adsorpsi zeolit terhadap logam merkuri (II) optimum terjadi pada $\mathrm{pH}$ 6, kesetimbangan adsorpsi cenderung mengikuti pola isoterm Freundlich dengan konstanta yaitu 1,803 x $10^{-4}$ $\mathrm{mol} /$ gram dan kinetika adsorpsi cenderung mengikuti persamaan pseudo orde dua dengan konstanta laju reaksi $(\mathrm{k})$ yaitu $8,687 \times 10^{-3}(\mathrm{~g} / \mathrm{mg} \mathrm{min})$.
\end{abstract}

Kata kunci : Abu dasar batubara, zeolit, adsorpsi, merkuri (II)

\begin{abstract}
Synthesis of zeolite from charcoal bottom ash and it's application as adsorbent for mercury (II) has been done. Zeolite was synthesized from charcoal bottom ash using hydrothermal methods and characterized by FTIR and XRD. Adsorption of mercury (II) using synthesized zeolite was performed with $\mathrm{pH}$ variation, contact time and mercury concentration. FTIR characterization results showed that charcoal bottom ash has been successfully transformed into zeolite with specific absorption on $457,31 \mathrm{~cm}^{-1}$. X-Ray Diffractions characterization results showed that the zeolite type is Faujasites with difraction peaks on $6,29^{\circ} ; 26,89^{\circ}$; dan $31,19^{\circ}$. Adsorption of mercury (II) using the synthesized zeolites showed an optimum $\mathrm{pH}$ on 6 . The isoterm data can be best described by the Freundlich equation with the constant of $1,803 \times 10^{-4}$ mole/gram and adsorption kinetic followed the pseudo second order kinetic model with $8,687 \times 10^{-3}(\mathrm{~g} / \mathrm{mg} \mathrm{min})$ adsorption rate constant.
\end{abstract}

Keyword: Bottom ash, Zeolites, adsorbtion, mercury (II)

\section{PENDAHULUAN}

Perkembangan industri yang semakin banyak pada saat ini, menyebabkan bertambahnya limbah yang dihasilkan. Pengolahan limbah industri yang belum maksimal dapat menyebabkan pencemaran lingkungan. Salah satu sumber pencemaran berasal dari limbah industri yang mengandung logam berat. Logam-logam berat 
biasanya berasal dari proses-proses industri seperti industri metalurgi, industri penyamakan kulit, industri pembuatan fungisida, industri cat dan zat warna tekstil (Redhana, 1994). Ion-ion logam berat merupakan racun bagi organisme serta sangat sulit diuraikan secara biologi maupun kimia.

Salah satu logam berat yang dapat mencemari lingkungan adalah logam merkuri. Merkuri dengan jumlah konsentrasi tinggi mempunyai potensi sebagai polutan yang bersifat toksik. Oleh karena itu, U.S. Food and Administration (FDA) menentukan pembakuan atau ambang batas kadar merkuri di dalam tubuh badan air sebesar 0,005 ppm. Apabila melebihi ambang batas maka racun yang dimiliki merkuri dapat menyebabkan dampak negatif diantaranya penyempitan pada medan penglihatan, gangguan akomodasi dan keseimbangan otot mata (Sudarmadji, 1997). Salah satu upaya untuk menanggulangi dampak negatif logam merkuri yaitu menggunakan metode yang dapat menyerap logam berat tersebut. Bahan untuk adsorben yang murah dan mudah diperoleh adalah limbah sisa pembakaran batubara. Limbah abu batubara dapat dikonversi menjadi adsorben, salah satunya adalah zeolit (Munawaroh, 2012).

Abu layang memiliki kandungan $\mathrm{Si}$ sebesar 56,13\% dan $\mathrm{Al}$ sebesar 18,49\%, sedangkan abu dasar mengandung Si dan Al sebesar 50,58\% dan 14,99\% (Kula, 2008). Kandungan abu dasar yang relatif sedikit dan adanya senyawa pengotor lain, menyebabkan para peneliti tidak banyak melakukan sintesis zeolit dari abu dasar batubara. Padahal dalam pembakaran batu bara jumlah abu dasar yang dihasilkan umumnya lebih banyak dibandingkan abu layang. Potensi tersebut memungkinkan untuk mengkonversi abu dasar menjadi bahan adsorben dengan kemampuan yang lebih baik seperti zeolit. Zeolit memiliki kestabilan termal yang tinggi, struktur kristalnya berpori dan luas permukaan yang besar (Karmila, 2006).

Sintesis zeolit dari abu layang atau abu dasar umumya dilakukan dengan cara ekstraksi. Prosedur eksraksi dilakukan untuk mengambil komponen silikat dan aluminat dari abu dasar untuk disintesis menjadi zeolit (Chandrasekhar dkk, 2008). Ekstraksi abu dasar batu bara dilakukan mengunakan $\mathrm{NaOH}$ dengan massa 1:1,2 pada suhu tinggi yang dikenal dengan peleburan dilanjutkan proses hidrotermal (Yanti,2009 dan Suci,2009). Hasil sintesis menunjukkan terbentuk zeolit A yang memiliki kristalinitas dan kemurnian tinggi.

\section{METODE PENELITIAN}

\section{Bahan dan Alat}

Bahan yang digunakan antara lain adalah abu dasar, $\mathrm{NaOH}$ (E. Merck), $\mathrm{HgCl}_{2}$, larutan $\mathrm{SnCl}_{2}, \mathrm{KMnO} 4, \mathrm{HCl}$ pekat (E. Merck), larutan hidroksilamin asetat, akuades, kertas $\mathrm{pH}$ dan kertas whatman no.42.

Alat-alat pecobaan yang digunakan dalan penelitian ini adalah, hot plate, pompa vakum, oven, neraca analitik, gelas arloji, cawan penguapan, pipet ukur, furnace, shaker, lumpang porselen, gelas beker, labu ukur, $\mathrm{Ph}$ meter (CyberScan 1000), mikro pipet, XRD powder (Philips tipe PW1710), merkuri analizer, Fourier Transform Infra Red (FT-IR) Thermo Nicolet Avatar 360.

\section{Prosedur Penelitian}

\section{Perlakuan Abu Dasar Batubara}

Abu dasar batubara yang masih berbentuk batuan dari Pabrik Spirtus Madukismo dihaluskan dengan cara ditumbuk dan digerus menggunakan lumpang dan mortar porselen. Setelah halus, abu dasar diayak 230 mesh dan dikeringkan pada temperatur $105^{\circ} \mathrm{C}$ selama 2 jam. 


\section{Sintesis Zeolit dari Abu Dasar Batubara}

Abu dasar di campur dengan $\mathrm{NaOH}$ pelet dengan perbandingan massa abu dasar 1:1,2 kemudian digerus hingga tercampur. Campuran dimasukkan dalam crus nikel dan dipanaskan pada suhu $550^{\circ} \mathrm{C}$ selama 60 menit dalam muffle furnace. Hasilnya dimasukkan dalam gelas beker, ditambahkan $10 \mathrm{~mL}$ akuades kemudian diaduk dengan pengaduk magnet selama 24 jam. Selanjutnya dimasukkan dalam reaktor hidrotermal (autoclave stainless-steel) pada temperatur $100^{\circ} \mathrm{C}$ selama 24 jam. Padatan dipisahkan dengan kertas saring, dinetralkan dengan akuades dan dikeringkan dalam oven pada temperatur $100^{\circ} \mathrm{C}$ selama $1 \mathrm{jam}$.

\section{Studi Adsorpsi Zeolit Terhadap Larutan Merkuri}

a. Variasi $\mathrm{pH}$

Sejumlah $20 \mathrm{~mL}$ larutan merkuri (II) dengan konsentrasi 15 ppmdivariasi $\mathrm{pH}$ larutan mulai dari $\mathrm{pH} \mathrm{2,} \mathrm{3,} \mathrm{4,} \mathrm{5,} \mathrm{6,} 7$ dan 8 ditambahkan adsorben zeolit sintesis 0,1 $\mathrm{g}$ dandimasukkan ke dalam gelas beker $25 \mathrm{~mL}$. Kemudian diaduk selama 4 jampada kecepatan $170 \mathrm{rpm}$ dan pada suhu ruang. Larutan di pisahkan danfiltarnya diambil $10 \mathrm{~mL}$. Kemudian dianalisis menggunakan mercury analizer.

\section{b. Variasi konsentrasi awal adsorpsi}

Percobaan ini dilakukan dengan cara mengambil $20 \mathrm{~mL}$ larutan merkuri(II) dengan variasi konsentrasi 4, 8, 12 dan 16 ppm, masing - masing larutan ditambahkan adsorben zeolit sintesis 0,1 g. Kemudian di aduk selama 4 jam pada kecepatan $170 \mathrm{rpm}$. Larutan di pisahkan dan filtratnya diambil $10 \mathrm{~mL}$. Kemudian dianalisis menggunakan mercury analizer.

c. Variasi waktu kontak adsorpsi

20 ml larutan merkuri (II) dengan konsentrasi 15 ppm dimasukkan ke dalam erlenmeyer $25 \mathrm{ml}$, selanjutnya ke dalam masing - masing larutan dimasukkan adsorben zeolit sintesis sebanyak $0,1 \mathrm{~g}$ mulai dari $5,15,25,35,45,55,65,75$, $85,95,105,115,125,135,145$ dan 155 menit. Larutan dipisahkan dan filtratnya diambil $10 \mathrm{~mL}$. Kemudian dianalisis menggunakan mercury analyzer.

\section{HASIL DAN PEMBAHASAN}

\section{Karakterisasi Zeolit Sintesis dengan Difraksi Sinar-X}

Karakterisasi zeolit dilakukan pada rentang sudut $2 \theta$ sebesar 10-90. Berdasarkan informasi basic data process XRD difraktogram, diperoleh 15 puncak utama yang memiliki intensitas relatif besar mengindikasikan pola difraksi zeolit seperti ditunjukkan Gambar 1 dan Tabel 1. Pola difraksi dengan intensitas yang tinggi dan tajam mengindikasikan material zeolit hasil sintesis memiliki kristalinitas yang cukup besar atau struktur mineral yang teratur. Zeolit apabila dalam bentuk kristalnya akan memperlihatkan spektrum yang runcing menandakan bahwa susunannya lebih teratur. Sedangkan bila masih dalam bentuk amorfnya spektrum akan terlihat melebar. Sedangkan adanya puncakpuncak kecil yang terlihat dalam spektum menunjukkan adanya pengotor lainya seperti adanya puncak tinggi dan tajam pada $2 \theta=20,8^{\circ}$ dan $26,54^{\circ}$ menunjukkan adanya mineral kuarsa. 


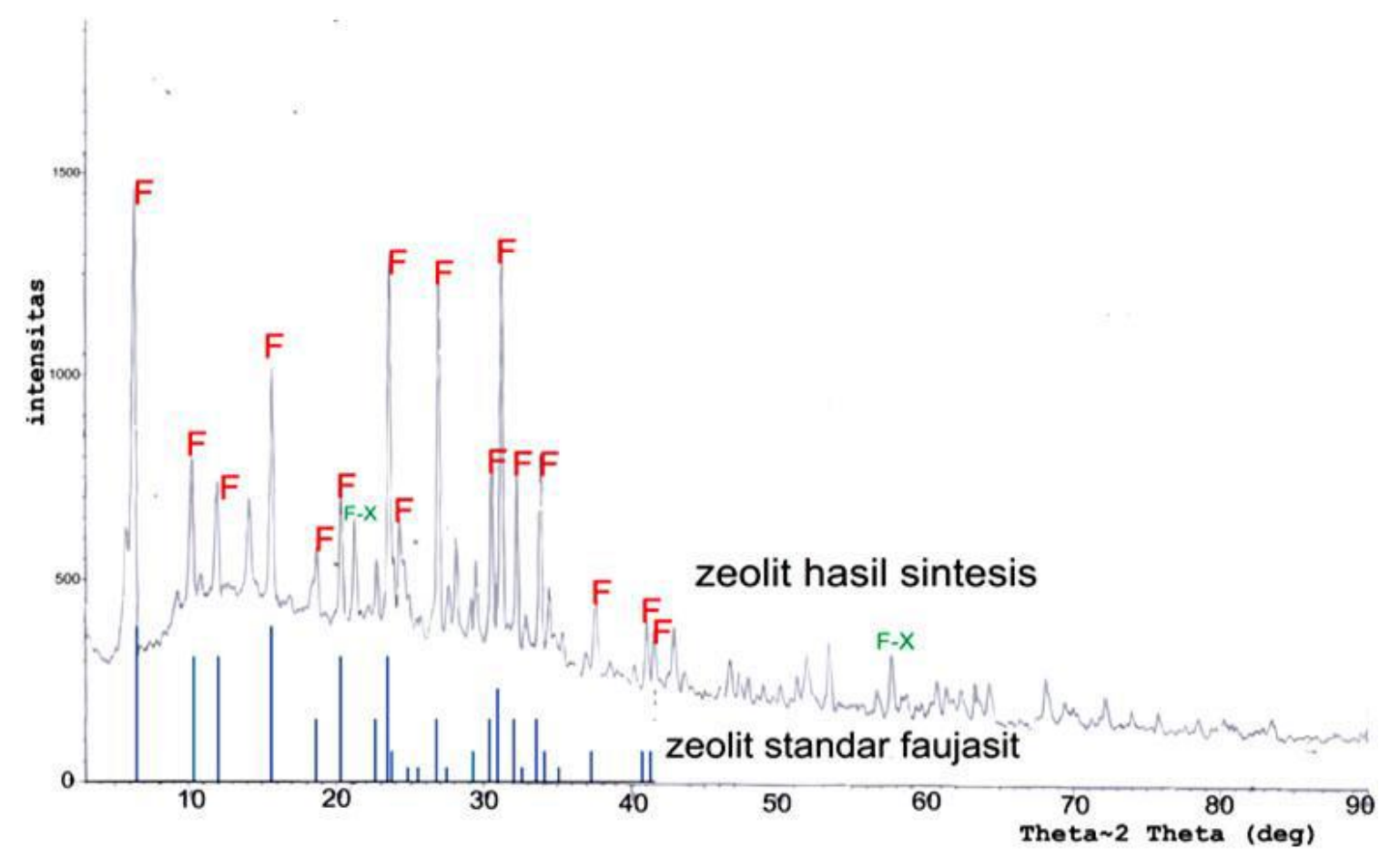

Gambar 1. Difraktogram sinar X zeolit sintesis dan zeolit faujasit

Tabel 1. Interpretasi Relatif Difraksi sinar-X zeolit sintesis dengan faujasit standar

\begin{tabular}{|l|c|c|r}
\hline No. & $\begin{array}{c}\text { Faujasit Standar } \\
\text { JCDS }\end{array}$ & $\begin{array}{c}\text { Zeolit } \\
\text { sintesis }\end{array}$ & \multicolumn{1}{|}{ I } \\
\cline { 2 - 3 } & $2 \theta$ & $2 \theta$ & \\
\hline 1. & $6,181^{\circ}$ & $6,2946^{\circ}$ & Zeo \\
2. & $26,845^{\circ}$ & $26,8954^{\circ}$ & Zeo \\
3. & $31,196^{\circ}$ & $31,1903^{\circ}$ & Zeo \\
4. & $10,109^{\circ}$ & $10,1825^{\circ}$ & Zeo \\
5. & $15,518^{\circ}$ & $15,6424^{\circ}$ & Zeo \\
6. & $20,228^{\circ}$ & $20,3065^{\circ}$ & Zeo \\
7. & $22,619^{\circ}$ & $22,7047^{\circ}$ & Zeo \\
8. & $23,752^{\circ}$ & $23,8800^{\circ}$ & Zeo \\
9. & $24,870^{\circ}$ & $24,8600^{\circ}$ & Zeo \\
10. & $29,439^{\circ}$ & $29,4621^{\circ}$ & Zeo \\
11. & $32,258^{\circ}$ & $32,2407^{\circ}$ & Zeo \\
12. & $32,817^{\circ}$ & $32,8565^{\circ}$ & Zeo \\
13. & $33,824^{\circ}$ & $33,8454^{\circ}$ & Zeo \\
14. & $53,377^{\circ}$ & $53,4397^{\circ}$ & Zeo \\
15. & $21,238^{\circ}$ & $21,2369^{\circ}$ & Zeo \\
\hline
\end{tabular}

\section{Karakterisasi Zeolit Sintesis dengan Spektrofotometer Inframerah}

Berdasarkan data spektra inframerah zeolit sintesis memperlihatkan pita serapan pada bilangan gelombang 3473,44; 1643,$67 ; \quad 981,41 ; \quad 747,27$; 667,49 ; dan 457,31 $\mathrm{cm}^{-1}$. Bilangan gelombang $3700-3400 \mathrm{~cm}^{-1}$ berhubungan dengan gugus hidroksil (-OH) dari molekul $\mathrm{H}_{2} \mathrm{O}$ yang merupakan vibrasi rentang (ulur) dari gugus silanol (Si-OH). Gugus ini dimungkinkan merupakan suatu air hidrat yang berasal dari kristal (Hamdan, 2007) yang terdapat pada permukaan padatan dimana dalam zeolit sintesis muncul pada bilangan gelombang $3473,44 \mathrm{~cm}^{-1}$.

Pita serapan pada bilangan gelombang 1643,67 $\mathrm{cm}^{-1}-1641,81 \mathrm{~cm}^{-1}$ menunjukkan adanya vibrasi bengkokan (tekuk) $\mathrm{O}-\mathrm{H}$ dari gugus silanol $(\mathrm{Si}-\mathrm{OH})$ dimana dalam zeolit sintesis muncul pada bilangan gelombang 1643,67 $\mathrm{cm}^{-1}$. Kemunculan pita serapan pada bilangan gelombang ini terjadi karena adanya 
penyerapan air dari udara oleh sifat zeolit yang cukup higroskopis.

Bilangan gelombang yang muncul lebih sempit dengan puncak $981,4 \mathrm{~cm}^{-1}$ menunjukkan adanya vibrasi asimetris internal $\mathrm{Si}-\mathrm{O}$ atau Al-O dalam Si-O ${ }_{4}$ atau $\mathrm{TO}_{4}$ tetrahedral. Penyempitan pita serapan berhubungan dengan bertambah homogennya jenis spesies $\mathrm{Si}$ dan Al setelah proses sintesis (Sunardi, 2007). Pita serapan pada daerah $850-650$ $\mathrm{cm}^{-1}$ merupakan hasil vibrasi rentangan simetris, yaitu suatu vibrasi internal pada $720-650 \mathrm{~cm}^{-1}$ dan vibrasi eksternal pada $780-720 \mathrm{~cm}^{-1}$. Pita serapan kecil dan tajam pada zeolit sintesis terdapat dalam bilangan gelombang 747,27 $\mathrm{cm}^{-1}$ dan $667,49 \mathrm{~cm}^{-1}$ menunjukkan vibrasi eksternal dan internal rentangan simetris $\mathrm{T}-\mathrm{O}$, dimana pita tajam tersebut menunjukkan adanya kristalinitas yang cukup tinggi.

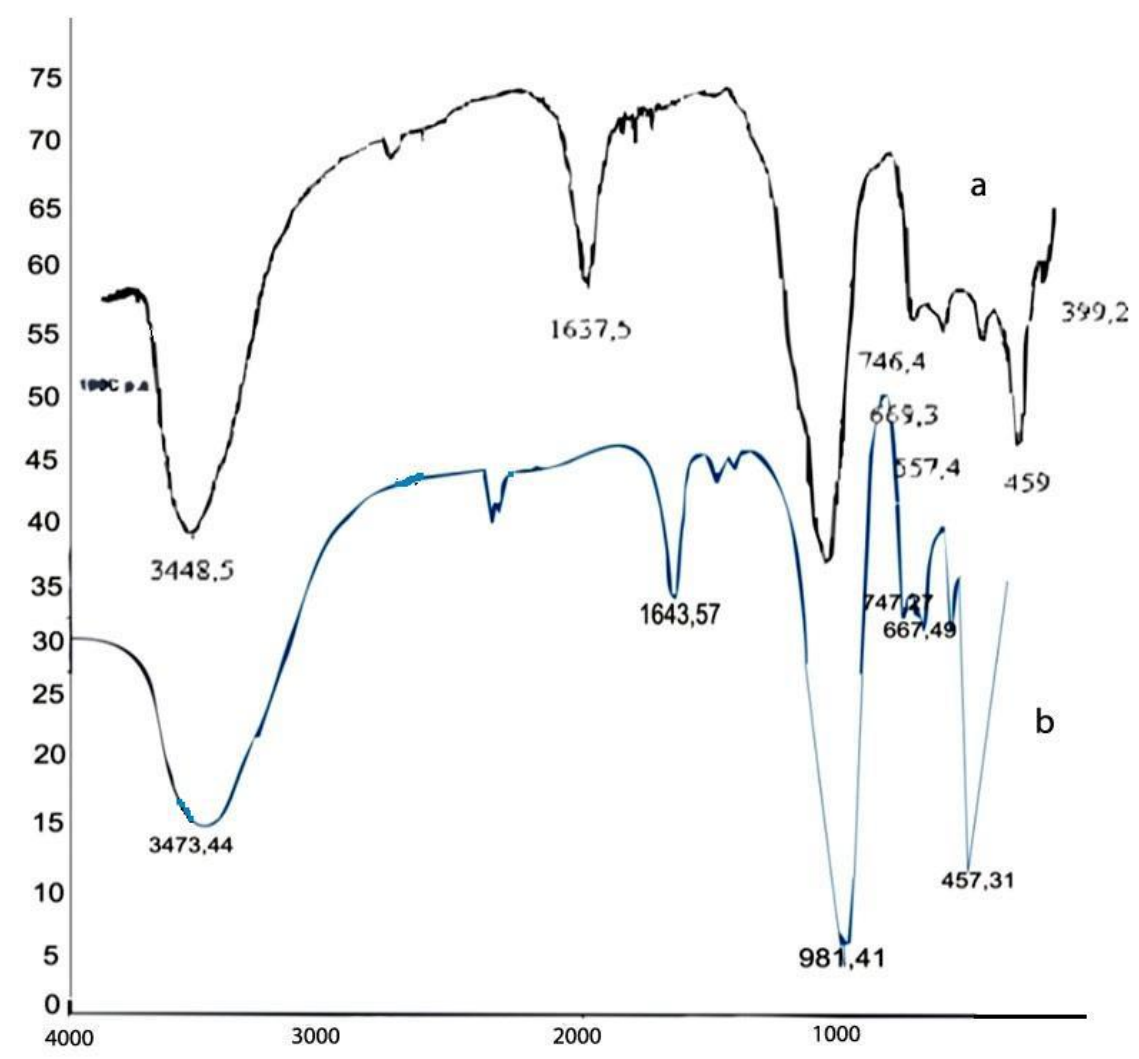

Gambar 2. Pola Spektra FTIR (a) zeolit faujasit dan (b) zeolit sintesis

Sedangkan, serapan bilangan gelombang 457,31 $\mathrm{cm}^{-1}$ menunjukkan vibrasi bengkokan (tekuk) ikatan SiO/Al-O. Dari difraksi sinar $\mathrm{X}$ yang dikuatkan dengan hasil FTIR maka dapat diperkirakan bahwa zeolit yang terbentuk adalah tipe faujasit. Hal tersebut diperkuat dengan adanya serapan vibrasi bengkokan (tekuk) T-O (Si-O/Al-O) antara daerah panjang gelombang 475$450 \mathrm{~cm}^{-1}$ sesuai dengan vibrasi tekuk T-O milik zeolit tipe faujasit.

\section{Adsorpsi pada zeolit sintesis}

\section{Variasi pH}

Pengaruh $\mathrm{pH}$ terhadap absorpsi merkuri (II) oleh zeolit dilakukan pada $\mathrm{pH} 2,3,4,5,6,7$ dan 8 dengan hasil ditunjukkan gambar 3. Hal ini bertujuan untuk mengetahui kondisi $\mathrm{pH}$ pada saat interaksi dengan adsorbendalam menyerap adsorbat secara optimum. Kajian interaksi merkuri (II) dengan situs 
aktif pada sintesis zeolit dilakukan dengan mengevaluasi data pengamatan pengaruh $\mathrm{pH}$ larutan terhadap jumlah merkuri (II) yang teradsorpsi.

Pada Gambar .3 tersebut diketahui bahwa kapasitas adsorpsi pada pHasam lebih kecil, apabila $\mathrm{pH}$ semakin basa kapasitas adsorpsi semakin besar danoptimum pada $\mathrm{pH}$ 6. Hal tersebut karena situs tepi zeolitmerupakan situs yang muatannya bervariasi tergantung pada harga $\mathrm{pH}$ larutan, bermuatanpositif pada $\mathrm{pH}$ asam (rendah) dan bermuatan negatif pada $\mathrm{pH}$ basa (tinggi)sebagai akibat protonasi dan deprotonasi gugus hidroksil permukaan (SOH) (Widjajanti, 2011). Reaksi protonasi dan deprotonasi $\mathrm{SOH}$ dapat dinyatakan oleh persamaan berikut :

Pada $\mathrm{pH}$ rendah:

$$
\mathrm{SOH}+\mathrm{H}^{+} \rightarrow \mathrm{SOH}_{2}{ }^{+}
$$

Pada $\mathrm{pH}$ tinggi:

$$
\mathrm{SOH}+\mathrm{OH}^{-} \rightarrow \mathrm{SO}^{-}+\mathrm{H}_{2} \mathrm{O} \ldots(2)
$$

Keasaman permukaan zeolit (asam Bronsted Lowry atau asam Lewis) sangat berperan dalam pembentukan ikatan antar muka. Berarti permukaan zeolit mengalami reaksi protonasi atau permukaan zeolit memiliki situs aktif $\mathrm{SOH}_{2}{ }^{+}$. Hal ini disebabkan pada lapisan adsorben cenderung bermuatan positif sehingga dapat menurunkan kapasitas adsorpsi (Pratiwi dkk., 2010).
Hasil penelitian menunjukkan bahwa $\mathrm{Hg}^{2+}$ dari senyawa $\mathrm{HgCl}_{2}$ tetap larut dan stabil hingga mencapai $\mathrm{pH}$ optimum adsorpsi yaitu pH 6. Adsorpsi optimum pada $\mathrm{pH} 6$ karena pada $\mathrm{pH}$ ini belum terjadi pengendapan, selain itu situs tepizeolit sedang mengalami peningkatan deprotonasi sehingga terjadi adsorpsi secaraoptimum. Pada $\mathrm{pH}$ rendah kurang dari $\mathrm{pH} \mathrm{6,} \mathrm{merkuri} \mathrm{(II)} \mathrm{adalah} \mathrm{dalam}$ bentuk ion bebas dari $\mathrm{Hg}^{2+}$, dan adanya ion hidrogen bermuatan positif, hal ini dapatmengakibatkan terjadinya gangguan terhadap adsorpsi $\mathrm{Hg}^{2+}$ untuk mengikat situs di permukaan adsorben zeolit. Setelah permukaan adsorben terprotonasi, interaksi elektrostatik menurun, sehingga kapasitas adsorpsi lebih rendah pada $\mathrm{pH}$ rendah. Penurunan adsorpsi juga bisa terjadi karena struktur zeolit yang mudah rusak apabila terjadi adsorpsi pada suasana asam.

Pada $\mathrm{pH}$ yang lebih tinggi logam $\mathrm{Hg}^{2+}$ akan mengendap menjadi $\mathrm{HgO}$ dengan reaksi :

$\mathrm{Hg}^{2+}{ }_{(\mathrm{l})}+2 \mathrm{OH}_{(\mathrm{l})}^{-} \rightarrow \mathrm{HgO}_{(\mathrm{s})}+\mathrm{H}_{2} \mathrm{O}_{(\mathrm{l})} \ldots$. (3)

Sehingga semakin besar penambahan $\mathrm{pH}$ pada adsorben maka akan terjadi pengendapan $\mathrm{HgO}$, pengendapan yang terjadi ditandai dengan terbentuknya larutan bewarna kekuningan pada larutan air (Cay, 2001)

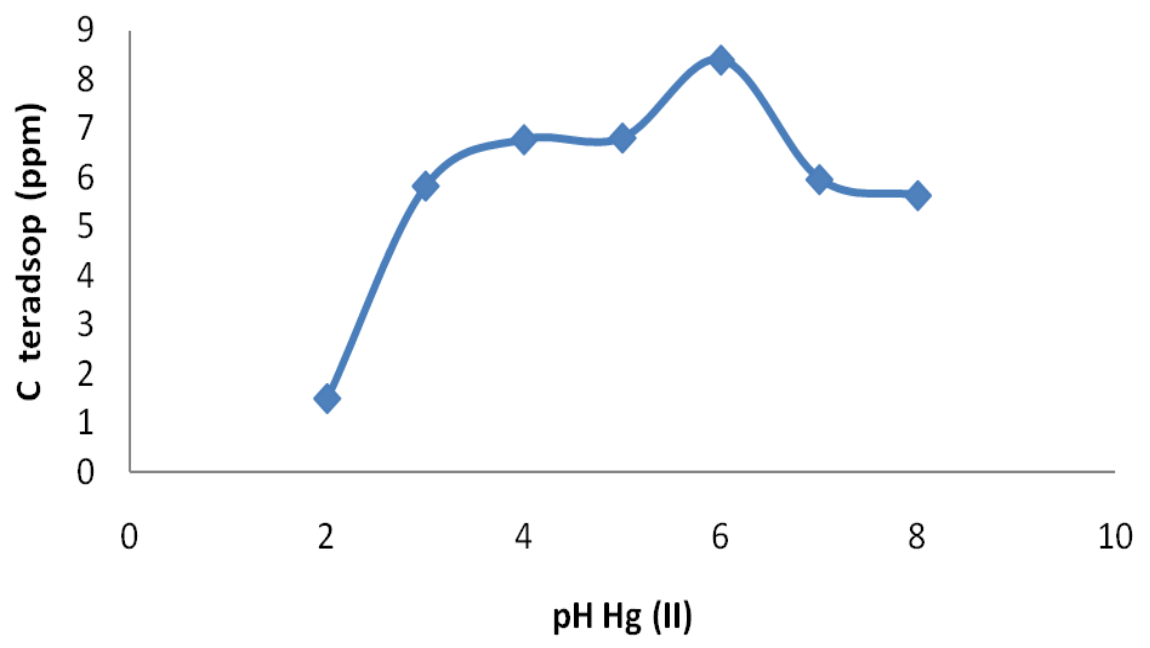

Gambar 3. Adsorpsi merkuri (II) dengan zeolit sintesis dengan variasi $\mathrm{pH}$ 


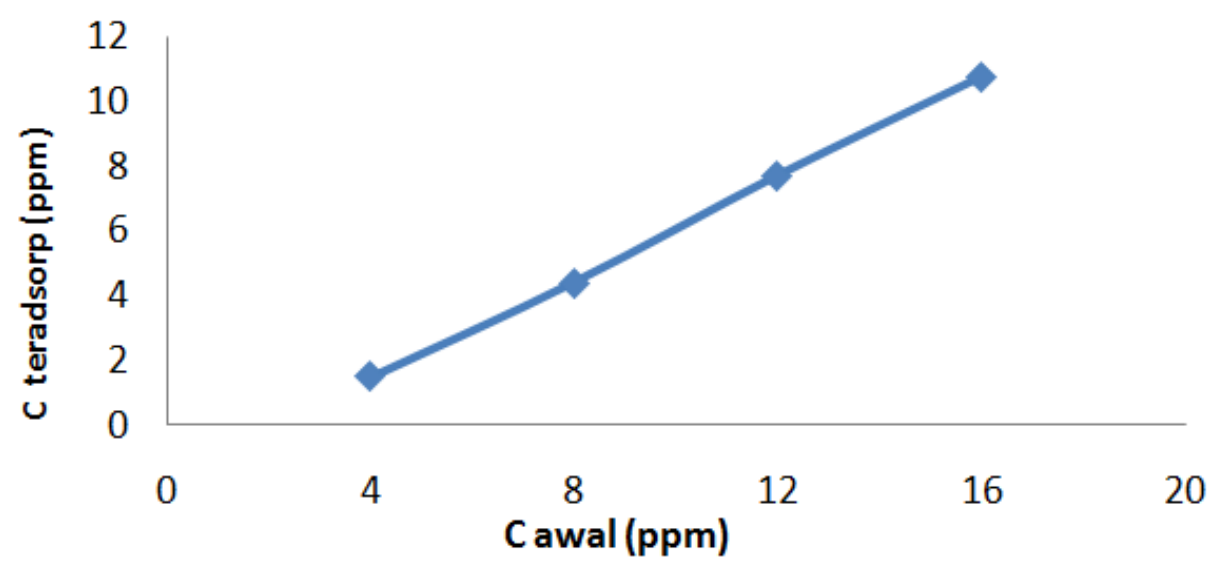

Gambar 4. Adsorpsi merkuri (II) dengan zeolit sintesis dengan variasi konsentrasi merkuri (II) mula-mula

\section{Kesetimbangan adsorbsi}

Pada Gambar 4 memperlihatkan bahwa semakin besar variasi konsentrasi logam merkuri (II) maka akan semakin besar adsorpsi yang terjadi dalam larutan. Peningkatan konsentrasi ini terjadi karena meningkatnya adsorbat dalam larutan yang dapat menempel pada permukaan zeolit. Hal ini menandakan bahwa lapisan luar permukaan zeolit belum mengalami kejenuhan karena masih terdapat banyak situs aktif dalam zeolit hasil sintesis yang dapat digunakan untuk mengadsorp logam merkuri (II), sehingga dari variasi konsentrasi 4-16 ppm terus mengalami peningkatan. Hal ini juga disebabkan karena semakin meningkatnya konsentrasi logam merkuri (II) maka akan memberikan daya dorong terhadap logam merkuri (II) untuk teradsorpsi (Minmin liu dkk., 2013).

Isoterm adsorpsi ini digunakan untuk menggambarkan hubungan antara adsorben dan zat yang teradsorp dalam suatu kesetimbangan. Biasanya ada dua model yang digunakan untuk menentukan isoterm adsorpsi yaitu menggunakan model isoterm Langmuir dan Freundlich. Data hasil isoterm adsorbsi pada Tabel 2 dapat diperoleh keterangan bahwa adsorpsi logam merkuri (II) menggunakan adsorben zeolit sintesis cenderung mengikuti persamaan Freundlich.

Tabel 2. Isoterm adsorpsi Langmuir dan Freundlich logam merkuri (II) pada zeolit sintesis

\begin{tabular}{|c|c|c|}
\hline Isoterm & $\mathrm{R}^{2}$ & Konstanta \\
\hline Langmuir & 0,755 & $\begin{array}{c}\mathrm{B}=-0,0335 \mathrm{~mol} / \mathrm{gram} \\
\mathrm{K}=-2,760 \times 10^{-8} \mathrm{~mol} / \mathrm{L}\end{array}$ \\
\hline Freunlich & 0,915 & $\begin{array}{c}1 / \mathrm{n}=1,227 \mathrm{n}=2,392 \times 10^{-3} \mathrm{~mol} / \mathrm{L} \\
\mathrm{K}=1,803 \times 10^{-4} \mathrm{~mol} / \mathrm{gram}\end{array}$ \\
\hline
\end{tabular}

Pola isoterm Freundlich mengamsusikan bahwa adsorpsi interaksi yang terjadi adalah secara fisika. Interaksi itu terjadi jika adanya gaya intermolekular yang lebih besar dari gaya tarik antar molekul atau gaya tarikmenarik yang relatif lemah antara adsorben dan adsorbat (Nurdiani, 2005). 
Adsorpsi fisika ini melibatkan gaya antar molekul yang relatif lemah, yaitu gaya Van der Waals dan dapat bereaksi balik (reversible). Gaya Van der Waals merupakan gaya dimana adsorbat dapat bergerak dari satu bagian permukaan ke bagian permukaan lain dari adsorben (Nur'aini, 2012).

Tipe isoterm Freundlich mengasumsikan adsorben mempunyai permukaan yang heterogen dan tiap molekul mempunyai potensi penyerapan yang berbeda-beda (Setyoningsih, 2010). Isoterm Freundlich juga menjelaskan bahwa proses adsorpsi pada bagian permukaan bersifat heterogen dimana tidak semua permukaan adsorben mempunyai daya adsorpsi yang sama (Bahri, 2011). Sehingga dapat digambarkan bahwa adsorbsi yang terjadi antara merkuri (II) pada permukaan zeolit sintesis memiliki ikatan fisika yang lemah dan heterogen yang dimungkinkan karena permukaan zeolit yang kurang seragam.

\section{Kinetika adsorbsi}

Data hasil pengamatan yang didapatkan dari Gambar 5 menunjukkan bahwa jumlah adsorbat yang terserap oleh adsorben dari 5 menit pertama sampai 135 menit menunjukkan peningkatan. Hal ini terjadi, karena awalnya banyak sisi adsorben yang belum berikatan sehingga kecenderungan larutan untuk terserap ke adsorben semakin tinggi dan seiring bertambahnya waktu maka adsorbat akan semakin mendekati pada adsorpsi optimun.

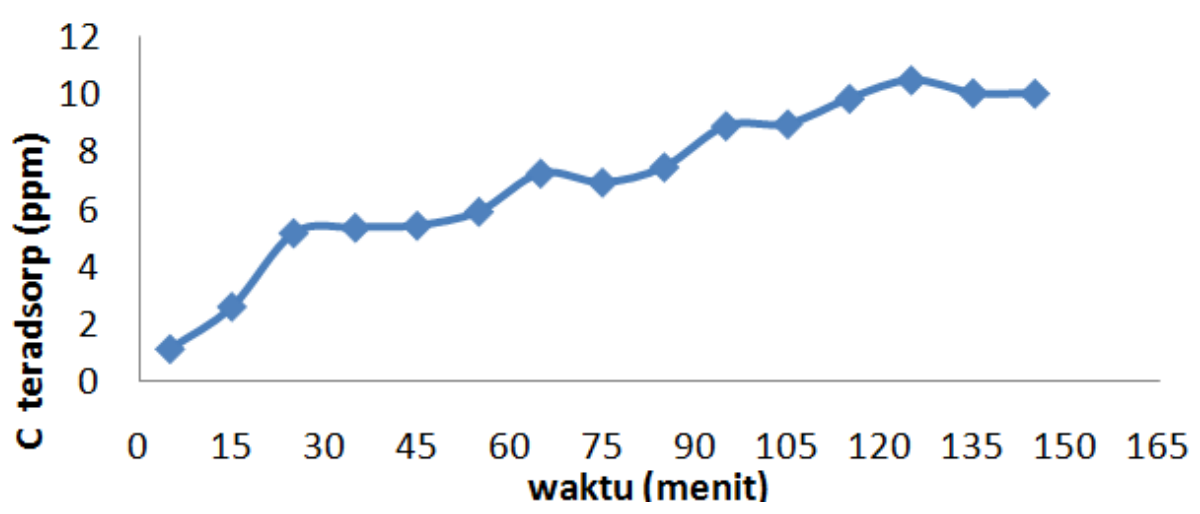

Gambar 5.Adsorpsi merkuri (II) dengan zeolit sintesis dengan variasi waktu

Tabel 3. Kinetika adsorbsi merkuri (II) pada zeolite sintesis

\begin{tabular}{ccc|ccc}
\hline \multicolumn{3}{c|}{ Pseudo orde satu } & \multicolumn{3}{c}{ Pseudo orde dua } \\
\hline $\mathrm{k}_{1}$ (menit $\left.^{-1}\right)$ & $\mathrm{q}_{\mathrm{e}}(\mathrm{mg} / \mathrm{g})$ & $\mathrm{R}^{2}$ & $\mathrm{k}_{2}(\mathrm{~g} / \mathrm{mg} \mathrm{min})$ & $\mathrm{q}_{\mathrm{e}}(\mathrm{mg} / \mathrm{g})$ & $\mathrm{R}^{2}$ \\
\hline 0,018 & 2,155 & 0,779 & $8,687 \times 10^{-5}$ & 2,551 & 0,909 \\
\hline
\end{tabular}

Penurunan adsorpsi pada adsorbat dengan adsorben terjadi setelah menit ke135. Semakin lama waktu kontak, situs aktif pada adsorben akan mengalami kejenuhan. Penambahan waktu tidak akan memberikan perubahan jumlah adsorbat yang terserap (Zakaria, 2011). Berkurangnya kemampuan penyerapan terjadi karena semakin lemah ikatan dan dimungkinkan adanya logam merkuri (II) yang kembali terlepas dari adsorben. Setelah waktu optimum adsorpsi tercapai, 
kapasitas adsorpsi (Q) cenderung menurun karena jumlah adsorben yangberikatan dengan adsorbat sudah dalam keadaan jenuhnya. Apabila ditambahkan waktu adsorpsi yang berlebih akan menyebabkan terjadinya proses desorpsi atau pelepasan kembali antara adsorben dan adsorbat (Fahrizal 2008).

Data yang telah didapatkan menunjukkan bahwa zeolit hasil sintesis dari abu dasar batubara ini dapat menyerap logam merkuri (II). Adanya variasi waktu interaksi antara adsorbat dengan adsorben, maka dapat dipelajari kenetika adsorpsi yang berlangsung dengan menggunakanbeberapa model kinetika. Kinetika adsorpsi merupakan salah satu faktor penting dalam proses adsorpsi karena menunjukkan laju penyerapan adsorben terhadap adsorbatnya. Model yang sering digunakan adalah model kinetika pseodo orde satu dan pseodo orde dua. Interaksi zeolit dengan logam merkuri (II) pada variasi waktu dapat ditentukan dari nilai orde reaksinya. Berdasarkan data pada Tabel 3 diperoleh bahwa adsorbsi logam merkuri (II) pada zeolite sintesis menikuti kinetika adsorbsi pseudo orde dua.

\section{KESIMPULAN}

1. Hasil karakterisasi XRD menunjukkan bahwa zeolit hasil sintesis memiliki difraksi $6,29^{\circ}$; $26,89^{\circ}$; dan $31,19^{\circ}$ yang bersesuaian dengan zeolit faujasit. Hasil karakterisasi FT-IR menunjukkan bahwa zeolit sintesis memiliki serapan pada daerah bilangan gelombang 457,31 cm $\mathrm{cm}^{-1}$ sesuai dengan vibrasi tekuk T-O milik zeolit tipe faujasit.

2. Adsorpsi logam merkuri (II) oleh zeolit dari abu dasar batubara optimum padapH 6.

3. Kesetimbangan adsorpsi cenderung mengikuti pola isoterm Freundlich dengan konstanta $(\mathrm{K})$ yaitu $1,803 \mathrm{x}$ $10^{-4} \mathrm{~mol} / \mathrm{g}$.

4. Kinetika adsorpsi cenderung mengikuti pseudo orde dua dengan nilaikonstanta laju reaksi (k) yaitu $8,687 \times 10^{-3}$ (g/mg min).

\section{UCAPAN TERIMAKASIH}

Ucapan terima kasih kami sampaikankepada Jurusan Kimia UIN Sunan Kalijaga Yogyakarta karena makalah ini merupakan bagian dari penelitian untuk memenuhi tugas akhir di Jurusan kimia.

\section{DAFTAR PUSTAKA}

Bahri, S., Muhdarina, Nurhayati, dan Fitri A., 2011, Isoterma dan Termodinamika Adsorpsi Kation $\mathrm{Cu} 2+$ Fasa Berair pada Lempung Cengar Terpilar, JurnalJurusan Teknik, Pekanbaru : FMIPA Universitas Riau.

Cay. Y., 2001, Mercury Contaminated Material Determination methods : investigation and assessment, $\mathrm{U}$. S. Departement of energy : Miami. Pp. 9

Chandrasekar, G., Kwang-Seok You JiWhan Ahn, Wha-Seung Ahn, 2008, synthesis of Hexagonal and Cubic Mesoporous Silica Using Power Plant Battom Ash, microporous and mesoporous Materials Vol 111 (1-3) 455-465

Fahrizal, 2008, Pemanfaatan Tongkol Jagung Sebagai Biosorben Zat Warna Biru Metilena, Skripsi kimia, Bogor : Fakultas MIPA IPB.

Karmila, Y., 2006, Sintesis dan Karakterisasi $\mathrm{TiO}_{2}-$ Zeolit Serta Aplikasi Bahan Tersebut Untuk Mendegradasi Zat Warna Methyl Orange dalam Media Air, Skripsi, Yogyakarta : FMIPA UGM. 
Kula O., 2000, "Effects of Colemanite Waste, Coal Bottom Ash and Fly Ash on The properties of cement", Journal of cement and concrete research, p.491-494.

Minmin Liu, Li-an Hou, Beidou Xi, Ying Zhao, and Xunfeng Xia, 2013, Synthesis, characterization, and mercury adsorption properties of hybridmesoporous aluminosilicate sieve prepared with fly ash, US National Library of Medicine National Institutes of Health

Munawaroh, I. 2012. Pemanfaatan Bonggol Jagung Sebagai Adsorben Rhodamin B dan Metanil Yellow, Skripsi, Yogyakarta : Fakultas Sains dan Teknologi UIN Sunan Kalijaga

Nur'aini, A., 2012, Sintesis Silika Gel Dari Abu Dasar Batubara Dan Uji Adsorpsi Terhadap Rhodamin, Skripsi Jurusan Kimia, Yogyakarta : F.Sains dan Teknologi. UIN Sunan Kalijaga.

Nurdiani, D., 2005, Adsorpsi Logam Cu (II) dan $\mathrm{Cr}$ (VI) pada Kitosan Bentuk Serpihan dan Butiran, Skripsi S-1 Jurusan Kimia, Bogor : Fakultas MIPA IPB.

Pratiwi, L., Ita Ulfin, dan Nurul W., 2010, Adsorpsi Metilen Biru dengan Abu Dasar PT. Ipmomi Probolinggo Jawa Timur dengan Metode Kolom, Prosiding Skripsi Semester Genap 2009/2010, Surabaya : Fak. MIPA Institut Teknologi Sepuluh

Redhana, I. W. 1994. Penentuan isoterm adsorpsi amonia dalam larutan air oleh karbon aktif pada suhu kamar. Bandung: Program Pra$S 2$ Kimia Pasca Sarjana. ITB.

Setyoningsih, 2010, Penggunaan Serat Daun Nanas Sebagai Adsorben Zat Warna Procion Red MX 8B,
Skripsi, Surakarta : Fakultas MIPA Universitas Sebelas Maret

Suci W. dan Nurul W,. 2010. Adsorpsi ion logam $\mathrm{Zn}^{2+}$ dengan zeolit $\mathrm{A}$ dengan metode batch. Zeolit A disintesis dari abu dasar dengan metode peleburan alkali diikuti proses hidrotermal. Prosiding Tugas Akhir Semester, Surabaya : Fakultas MIPA Institut Teknologi Sepuluh November.

Sudarmadji, S., Bambang H., dan Suhardi, 1997, Analisa Bahan Makanan dan Pertanian, Jakarta : Liberty

Sunardi dan Abdulah, 2007, Konversi Abu Layang Batubara Menjadi Zeolit dan Pemanfaatanya sebagai Adsorben Logam Merkuri (II), Jurnal Sains danTerapan Kimia, Vol. 1, No.1, Jurusan Kimia, Banjarbaru : FMIPA UNLAM.

Wijayanti, R., 2009, Arang Aktif Dari Ampas Tebu Sebagai Adsorben Pada Pemurnian Minyak Goreng Bekas, Jurnal Kimia, Bandung : FMIPA IPB

Yanti, Y., 2009, Sintesis Zeolit A dari Abu Dasar Batubara PT IPMOMI Paiton, Seminar Nasional Kimia, Jurusan Kimia, Surabaya : FMIPA ITS

Zakaria, A., 2011, Adsorpsi Cu (II) Menggunakan Zeolit Sintesis dari Abu Terbang Batubara, Tesis S-2, Bogor : Program Pascasarjana IPB. 